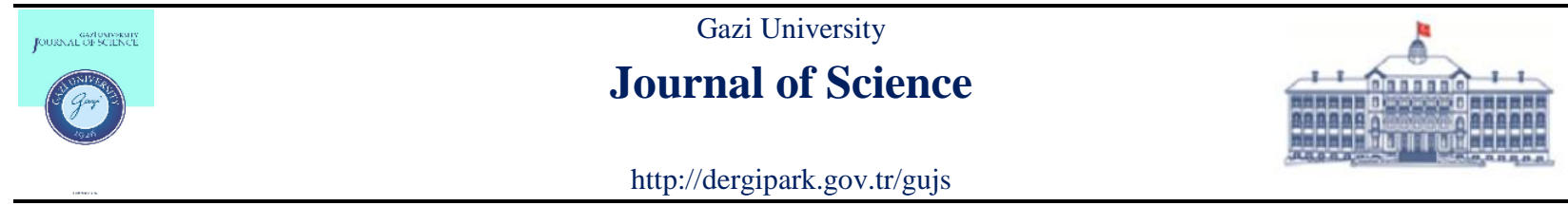

\title{
Contributions to the Systematics of the Genus Adonis L. (Ranunculaceae) in Turkey
}

\author{
Ali KANDEMIR ${ }^{1}$ (D) , Bahar KAPTANER IGCI ${ }^{2}$ (D) , Zeki AYTAC ${ }^{2 *}$ (D), Ahter FISNE² \\ ${ }^{I}$ Department of Biology, Faculty of Science and Art., Erzincan University, Erzincan, Turkey \\ ${ }^{2}$ Department of Biology, Faculty of Science, Gazi University, Ankara, Turkey

\section{Highlights} \\ - Re- evaluated of the status of the Adonis cyllenea var. paryadrica \\ - Information of pollen structure, ecology, conservation status and distribution map of the taxon \\ - Information of relationships with other close species
}

\begin{tabular}{l} 
Article Info \\
\hline Received: $28 / 11 / 2018$ \\
Accepted: $12 / 03 / 2019$ \\
Keywords \\
\hline Adonis \\
Erzincan \\
stat. nov \\
Ranunculaceae
\end{tabular}

\section{INTRODUCTION}

The genus Adonis is represented by approximately 40 species and two hybrids in the world [1-4]. 10 taxa are grown in Turkey (eight species, one subspecies, and one variety) [5]. Among these taxa, only A. cyllenea Boiss. Heldr. \& Orph. var. paryadrica Boiss. is endemic to Giresun/Gümüşhane provinces (Turkey). It was collected by Tchihatcheff in 1858 from Giresun.

Adonis annua L. is Mediterranean element; A. aleppica Boiss. and A. eriocalycina Boiss. are Ir.-Tr. elements and the others are widespread in Turkey. The petals colors of Adonis L. are usually scarlet in the genus members, but yellow in A. wolgensis Stev. ex DC, A. cyllenea var. paryadrica and A dentata Del.; scarlet to rarely yellow in A. microcarpa DC. in Turkey [6].

Except for A. wolgensis and A. cyllenea var. paryadrica, all Turkish Adonis species are annual. A. wolgensis is different from A. cyllenea with reduced to the scale of lower leaves and subuncinate achene beak [6].

The chromosome numbers of annual species change from $2 n=16$ to 48 and this number is $2 n=16 ; 24$ or 40 in perennials [7].

Anatolia was visited many times by foreign nature researchers, especially between the years 1800-2000 [8]. During these visits, biological, geological and archaeological samples were collected from different parts of Anatolia. Tchihatcheff was one of these researchers and collected many plant specimens especially from northern and eastern Anatolia. He published his plant samples in "Flore De Asie Mineure" [9]; but his plant 
samples were not well known in Turkey due to so many specimens placed in Flora orientalis and Flora of Turkey and the East Aegean Islands and some of them as only type specimens [9].

While Tchihatceff was traveling between Şebinkarahisar (Giresun) and Gümüşhane, he collected many plant specimens from the Paryados Mountains (now, between Licese and Kümbet near Şebinkarahisar); one of them belonged to the genus Adonis. This specimen was published as a new taxon by Boissier $A$. cyllenea var. paryadrica. [10]. Adonis cyllenea is endemic to Mount Killini (parts of Patras Island-Greece) [11]. Therefore, it would be more accurate to publish it as a taxonomic subspecies. However, it was published in Flora Orientalis as variety and its taxonomic situation in Flora of Turkey should be reevaluated $[6,10]$.

In 2014, Dr. Ali Kandemir collected similar specimens from Munzur Mountains (Erzincan part). These two samples were very similar to each other. However, the situation of A. cyllenea var. paryadrica has not been investigated in detail so far since additional samples was not collected after the type collection in 1856. After our examination, it is understood that the specimens in these two locations (Kandemir and Tchihatceff collections) belonged to A. cyllenea var. paryadrica when compared to each other. In this paper, we reevaluated the specimens and suggested to change the status of A. cyllenea var. paryadrica to the species level.

\section{MATERIALS AND METHODS}

The samples belonging to this species were collected in 2014 and 2017 in Kemah, Mercan Suyu, 1900 m, on a rocky place, Erzincan Province and Şebinkarahisar, Tutak Mountain, 2057 m, rocky slopes, Giresun Turkey. A. cyllenea var. paryadrica was re-described according to the collected materials, using Flora Caucasia [12], Flora Europeae [13], Flora of Turkey [6], Flora of USSR [14], Flora Orientalis [10] and Flora Hellenica [15]. The pollen and seed morphology of the species were examined with scanning electron microscopy (SEM) and photomicrographs were taken with the JEOL JSM 6060 SEM at the laboratory of Gazi University.

The names of the plants were checked from IPNI [4]. The terminology for pollen and seeds morphology was used in accordance with Faegri and Iversen [16] and Punt et al. [17]. The specimens used in this study are deposited at GAZI, ANK and NGBB. The author of plant names was used according to Brummitt and Powell [18].

\section{RESULTS}

\subsection{Taxonomic Order}

Familia: Ranunculaceae

Subfamilia: Ranunculoideae

Tribus: Adonideae

Genus: Adonis L.

Section: A. sect. Consiligo DC.

A. paryadrica (Boiss.) Kandemir \& Aytaç stat. nova. (Figure 1).

Type: TURKEY. A7 Giresun/Gümüşhane: In jugo Paryodrico Ponti austra., 1600 m, Tchihatcheff (G) photo!.

Second collection: TURKEY. A7 Giresun: Şebinkarahisar Tutak Mountain, $2057 \mathrm{~m}$, rocky slopes, 13.07.2017, Kandemir 10928; B7 Erzincan: Kemah, Mercan Suyu, 1900 m, 1900 m, rocky place, 26.05.2014, Kandemir 10548 and Y. Ünal. 
Re-description according to collected materials: Perennial, rhizomatus, branched from base; stem 50$70 \mathrm{~cm}$, sulcate, villose. Basal and lower leaves petiolate; petioles 5-15 cm; blade 10-14 cm long, with laciniae linear-setaceous, glabrous; upper cauline leaves similar to below, but smaller and sessile. Inflorescence always solitary; flowers 5-7 cm across. Sepals 2-2.5 cm, yellowish, membranous, glabrous. Petals 4-4.5 cm, yellow, with apiculate at apex. Stamens numerous; filaments $\pm 15 \mathrm{~mm}$, anthers 3-5 mm, villose. Achens numerous on globose receptaculum, 6-7 $63-4 \mathrm{~mm}$, glabrous, \pm pubescent, reticulate; beak 2.5-3 mm, circinnate. Fl. and Fr.: 5-6.

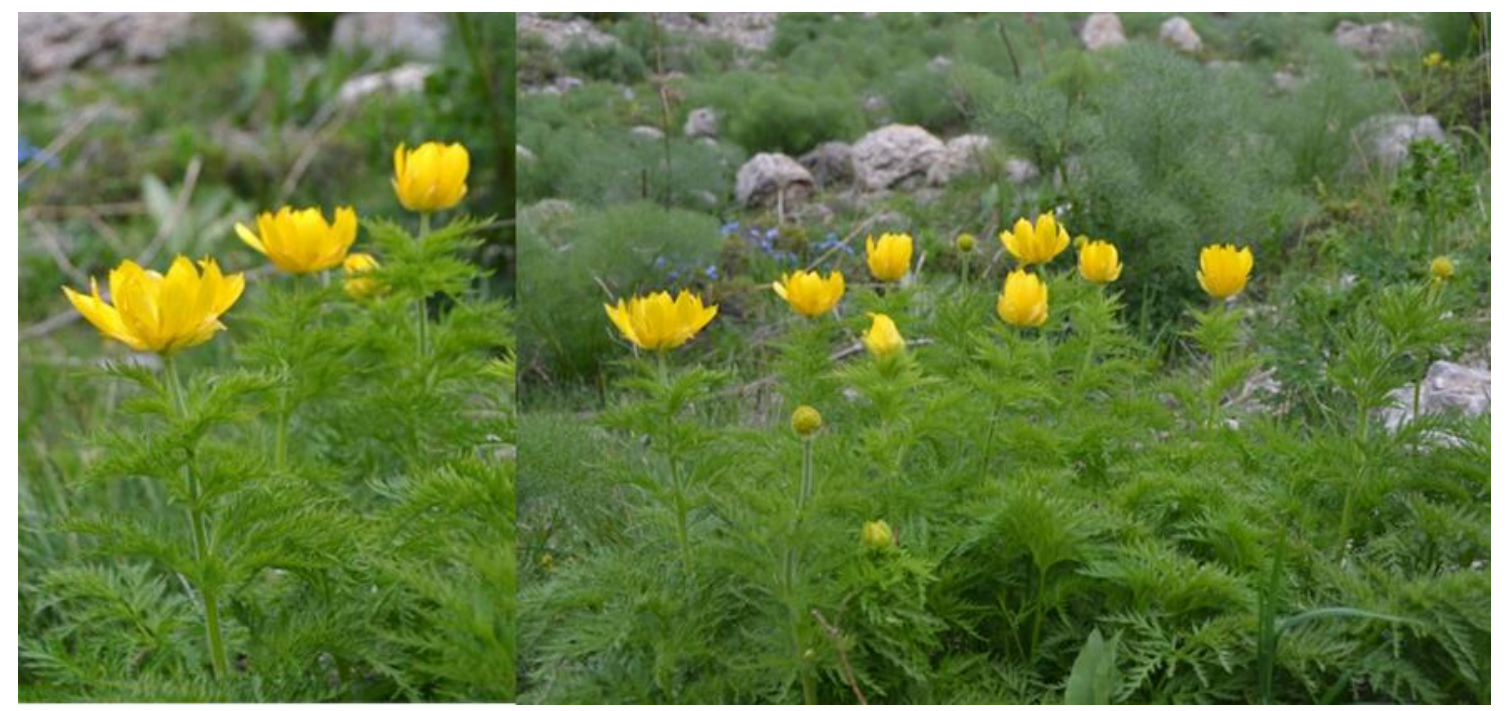

Figure 1. Habitus of A. paryadrica in the field with Prangos Lind. sp. population (Kandemir 10548 and Y. Unal)

\subsection{Pollen Structure}

Pollen grains of Adonis paryadrica are oblate-spheroidal, aperture tricolpate and ornamentation microechinate-perforate. $\mathrm{P}(\mu \mathrm{m})=(23.04) 25.73 \pm 1.72(28.8) . \mathrm{E}(\mu \mathrm{m})=(24) 27.19 \pm 1.57$ (29.76) (Figure 2).

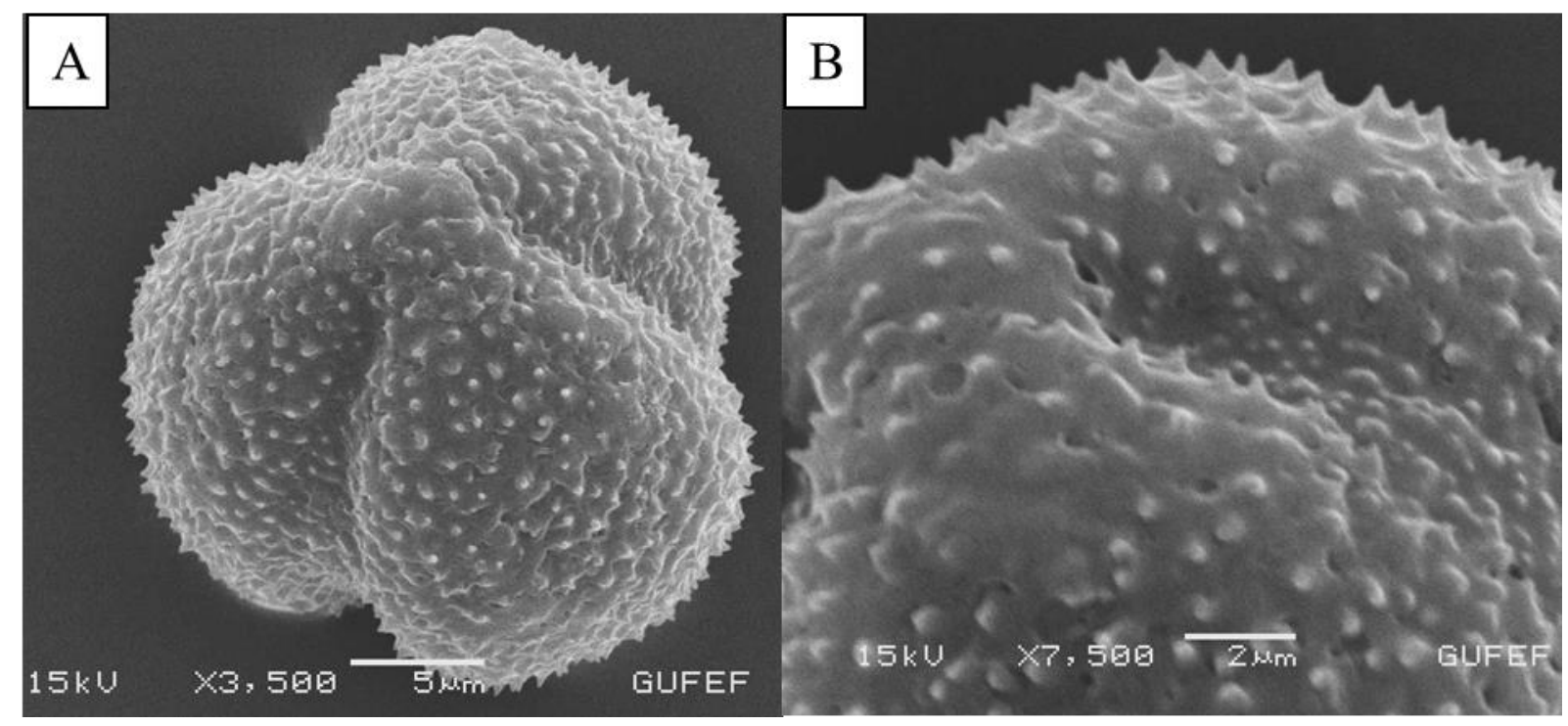

Figure 2. Pollen micrographs of A. paryadrica (A) Polar view, (B) Ornamentation. (Kandemir 10548 and Y. Ünal) 
The pollen grains are isopolar and tricolpate in annual and perennial species, but differt in size, shape and exin sculpturing. They are circular in polar view and elliptical in equatorial view in annual species; with prolate-suboblate shape and echinate sculpturing in A. wolgensis [3] also, oblate-spheroidal and microechinate-perfotate in A. paryadrica.

\subsection{Seed Structure}

Achenes are aggregate, sessile, nearly globose, rugose; beak is terminal, circinate (Figure 3).

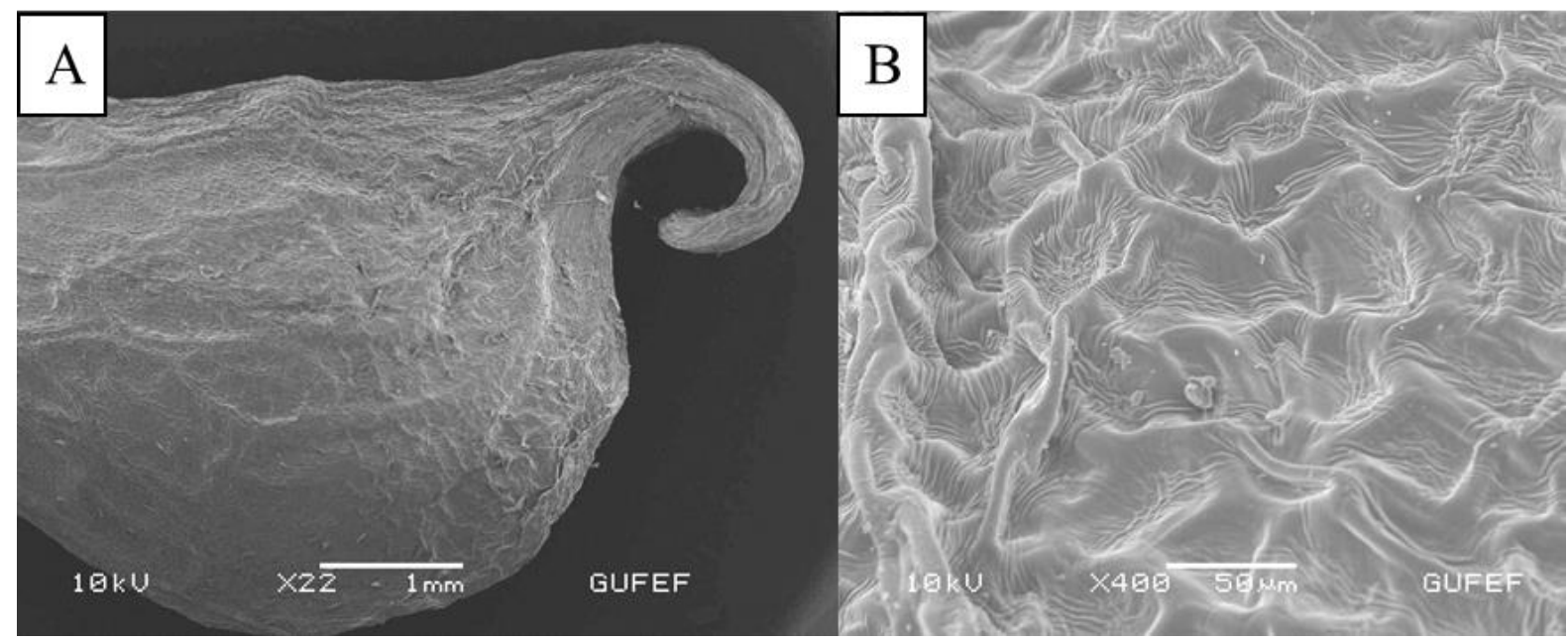

Figure 3. Achene micrographs of A. paryadrica. (A) general appearance, (B) ornamentation of seed coat surface (Kandemir 10548 and Y. Ünal)

\subsection{Distribution}

It is known from two collections, endemic. Irano.-Turanian element. (Figure 4).

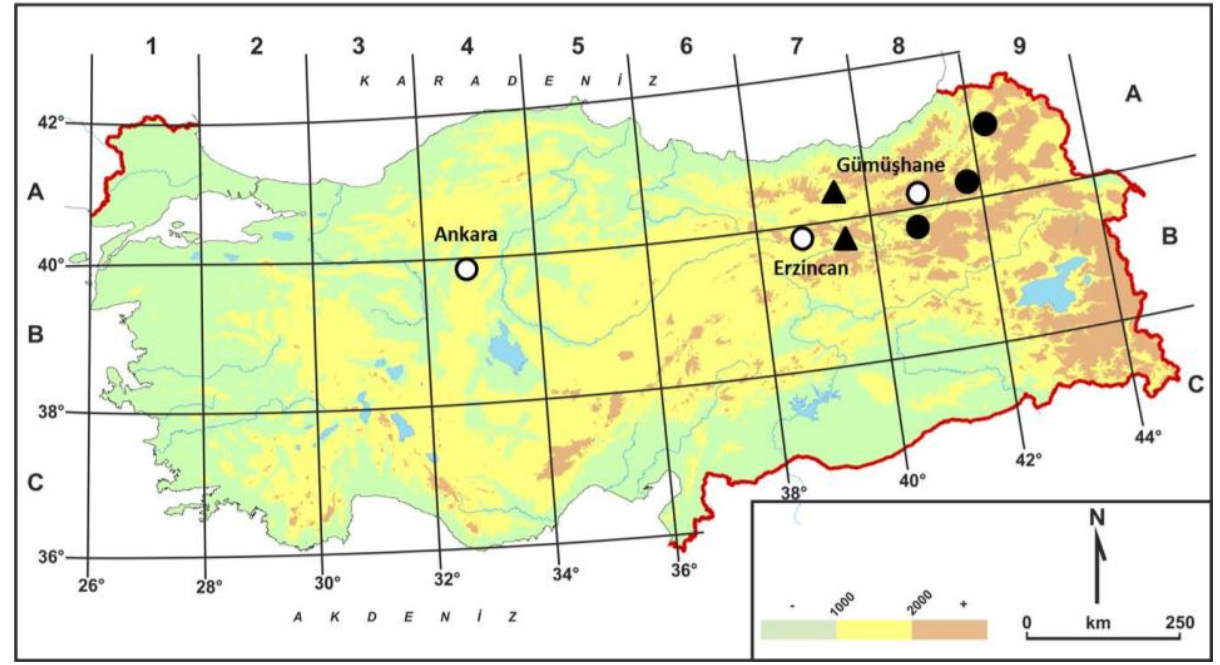

Figure 4. Distribution of $(\bullet)$ A.wolgensis and $(\mathbf{\Delta})$ A. paryadica.

\subsection{Ecology}

It grows on calcareous rocky slopes on the steppe, $1900 \mathrm{~m}$ altitude, the Prangos ferulacea Lindl is dominant species of the steppe. 


\subsection{Recommended IUCN Threat Category Listing}

It is known from two collections, B7 Kemah (Erzincan) and Şebinkarahisar (Giresun) (Figure 5). Additionally, it is Irano.-Turanian element. The estimated whole range is less than $10 \mathrm{~km}^{2}$. The population is unhealthy with less than 250 individuals due to grazing; the population of the species is threatened by extinction. Therefore, we recommend that the threatened categories of this species should be "Critically Endangered (CR)", (criteria B2 a b (i, iii) of IUCN 2010) [19].

\section{DISCUSSION}

In Turkey, four species of Adonis have yellow petals (A. microcarpa DC. rarely yellow, A. dentate Del., A. wolgensis Stev. ex DC and A. paryadrica (Boiss.) Kandemir \& Aytaç. Two of them are annual (A. microcarpa and A. dentate) and other two are perennial [6]. A. wolgensis and A. paryadrica are distinguished from each other by lower leaves and achene structure (Table 1).

A. cyllenea var. cyllenea grows in Killini Mt. (Greece). Adonis cyllenea var. paryadrica is known from Giresun and Gümüşhane provinces. These locations in Greece and Turkey are very distant from each other. In addition, the number of its leaves is less and the distribution of the leaves along the stem is more spaced in A. cyllenea var. cyllenea (Figure 5A), compared to A. cyllenea var. paryadrica.

A. paryadrica is distinguished from A. cyllenea by its more leafy stems, young carpels more densely pubescent, sepals $1 / 2$ to petals, and tall rhizomatous. The comparison of $A$. wolgensis, A. paryadrica and A. cyllenea are given in Table.

A. paryadrica (type specimen) is stored in G herbarium (Tchichatcheff, P. A., 464, 1858, Asia Minor Est. Mt Paryadras Ponti, Turkey, (G), G00330533). The photo of type material was examined (Figure 5 B). As a result of the examination, taxon was raised to the species level.

Table 1. Comparison of A. wolgensis and A. paryadrica

\begin{tabular}{|l|l|l|l|}
\hline & \multicolumn{1}{|c|}{ A. paryadrica } & \multicolumn{1}{c|}{ A. cyllenea } & \multicolumn{1}{c|}{ wolgensis } \\
\hline Lower leaves & Laminate and petiolate & petiolate & reduced to scale \\
\hline Sepals lenght & $1 / 2$ to petals & as long as petals & $2-3 \times$ shorter than petals \\
\hline Achenes & $\begin{array}{l}\text { pubescent, reticulate, with } \\
\text { strongly circinate beak }\end{array}$ & $\begin{array}{l}\text { pubescent reticulate, with } \\
\text { uncinated beak }\end{array}$ & $\begin{array}{l}\text { pubescent, not reticulate, } \\
\text { with subuncinate }\end{array}$ \\
\hline
\end{tabular}

The key of A.wolgensis and A. paryadrica was prepared according of Flora of Turkey [6].

1- Perennial and rhizomatous; anthers yellow (sect. Consiligo)

2- Lower leaves reduced to scales; achenes not reticulate, beak bent down-wards, subuncinate...................................................... wolgensis

2- Lower leaves laminate and petiolate; achenes reticulate, with long circinnate beak......................................................... paryadrica

1- Annual; anthers blackish (sect. Adonis, Turkish annual species)..other Turkish species 


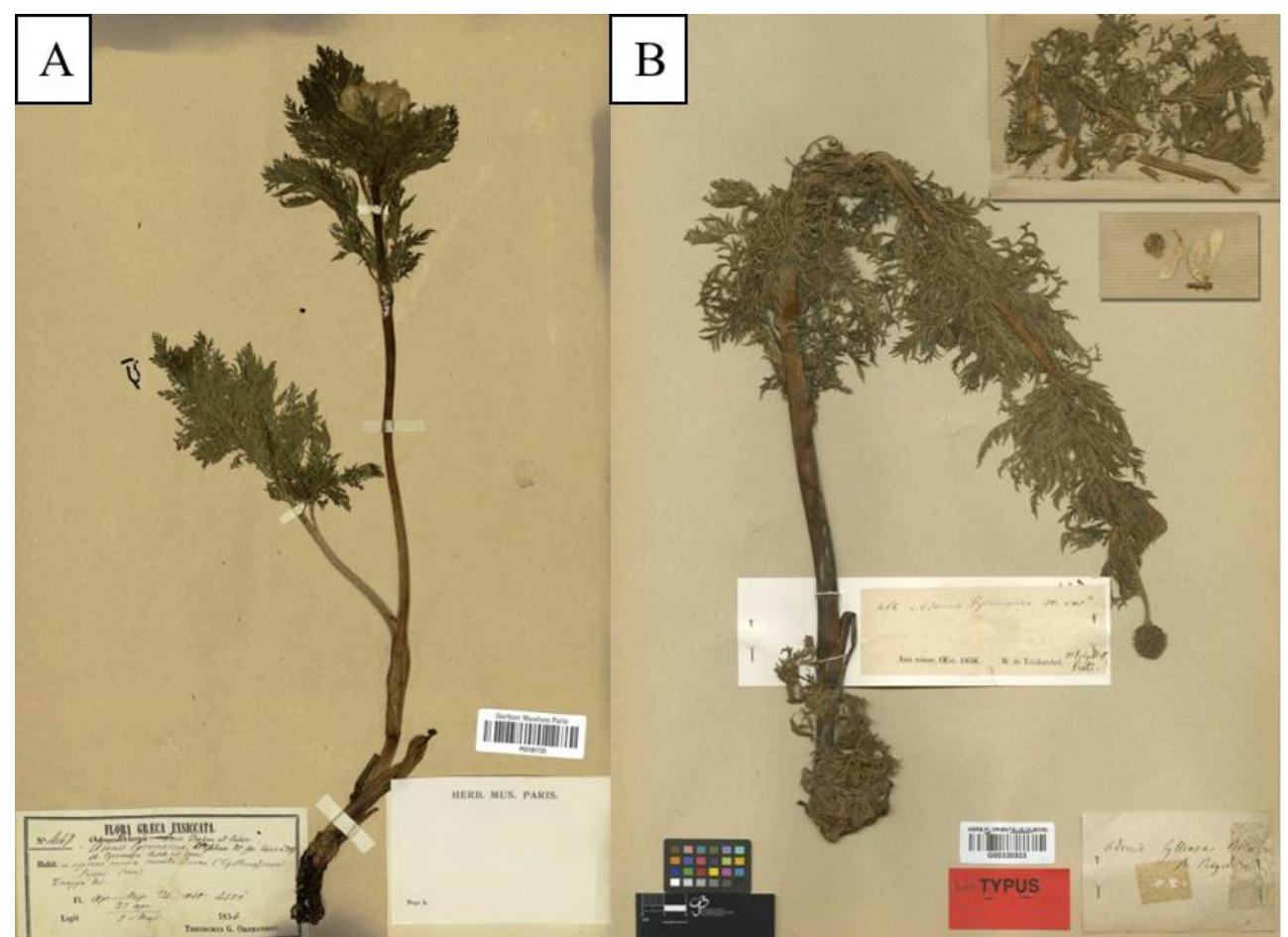

Figure 5. (A) holotype of Adonis cyllenea and (B) A. paryadrica

\section{ACKNOWLEDGMENTS}

The samples were collected from Munzur Mountains for the first time by Y1lmaz Unal who helped us during our collecting process. After the first collection by Tchihatceff, the samples were collected from type locality for the second time by Birdal Coşkun, Metin Kütükçü, Ertan Kuduban (the Director of Nature Conservation and National Parks of Giresun), Fatih Albayrak (the Chief of Nature Conservation and National Parks of Şebinkarahisar-Giresun), Ramazan Güzel and Y1ldız Gültepe (the members of Nature Conservation and National Parks of Şebinkarahisar.

\section{CONFLICTS OF INTEREST}

No conflict of interest was declared by the authors.

\section{REFERENCES}

[1] Wang W.T., "Revision of Adonis (Ranunculaceae)", I. Bull. Bot. Res., 14: 1-31, (1994a).

[2] Wang W.T., "Revision of Adonis (Ranunculaceae)", II. Bull. Bot. Res., 14: 105-138, (1994b)

[3] Ghorbani M.N., Azizian D., Sheidai M., Khatamsaz M., "Pollen Morphology of some Adonis L. species (Ranunculaceae) from Iran", Iran J. Bot., 14 (2): 2, (2008).

[4] IPNI, “The International Plant Names Index", http://www.ipni.org/ipni/authorsearchpage.do [accessed 16. 07. 2018], (2012).

[5] Güner Doğan E. “Adonis L. In: Güner A, Aslan S, Ekim T, Vural M, Babaç T (edts.) Türkiye Bitkileri listesi (Damarlı Bitkiler)", İstanbul: Nezahat Gökyiğit Botanik Bahçesi ve Flora Araştırmaları Derneği Yayını, (2012). 
[6] Davis P.H., "Adonis L. In: Davis PH, (ed.), Flora of Turkey and the East Aegean Islands", vol. 1, Edinburgh: Edinburgh Univ. Press, pp. 141-146, (1967).

[7] Heyn C.C., Pazy B., “The annual species of Adonis L. (Ranunculaceae) a polyploid complex”, P1. Syst. Evol., 168: 181- 193, (1989).

[8] Yıldırımlı Ş., Anadolu Botanik Tarihi. In Güner A \& Ekim T. (edts.) Resimli Türkiye Florası, Cilt 1, Ali Nihat Gökyiğit Vakıfı, Flora Araştırmaları Derneği ve Türkiye İş Bankası Kültür Yayınları, İstanbul, (2014).

[9] Tchihatcheff P.D., "Asie Mineure. Description Physique, Statistique et Archeolugique de cette contrée”, Botanique (Flore De L’Asie Mineure) vol 1-2. Paris, Gide, Librairie-Editure, (1860).

[10] Boissier E., "Flora Orientalis” vol. 1:15, Geneve, (1867).

[11] Kit T., Latrou G., "Endemic Plants of Greece the Peloponnese" Denmark, Copenhagen K., pp. 127$129,(2001)$

[12] Grossheim A.A., "Flora Caucasia”, vol. 4, Moscova; SSCB Scietific Akademy, (1950).

[13] Tutin T.G., Heywood V.H., Burges N.A., Valentine D.H., Walters S.M., Webb D.A., "Flora Europeae", vol. 1. Cambridge U. Press, pp. 122-123, (1964).

[14] Shishkin B.K. (editors), "Flora of the USSR", vol. 7, Israel Program for Scientific Translations: Jerusalem, pp.403-411, (1970).

[15] Runemark H.L.U., “Adonis L. In. Strid A, Tan K (eds.). Flora Hellenica”, vol. 2, A.R.G.Gantner: Verlag K.G. pp. 33-38, (2002).

[16] Faegri K., Iversen J., "Textbook of Pollen Analysis”, 4th ed. Chichester, pp. 328, (1989).

[17] Punt W., Hoen P.P., Blackmore S., Nilsson L., Thomas A., "Glossary of pollen and Spore Terminology. Review of Palaeobotany and Palynology”, 143 (1-2): 1-81, (2007).

[18] Brummitt R.K., Powell C.E. (eds.), “Authors of Plant Names”, Kew, UK: Royal Botanic Gardens (1992).

[19] IUCN, "The IUCN red list of threatened species. Version 2010.4” [accessed 16. 07. 2018], (2010). 